\title{
Analysis of Harrell Monosodium Titanate Lot \#46000619120
}

K. M. L. Taylor-Pashow

September 2012

Savannah River National Laboratory Savannah River Nuclear Solutions, LLC Aiken, SC 29808

Prepared for the U.S. Department of Energy under contract number DE-AC09-08SR22470. 
SRNL-STI-2012-00501

Revision 0

\section{DISCLAIMER}

This work was prepared under an agreement with and funded by the U.S. Government. Neither the U.S. Government or its employees, nor any of its contractors, subcontractors or their employees, makes any express or implied:

1. warranty or assumes any legal liability for the accuracy, completeness, or for the use or results of such use of any information, product, or process disclosed; or

2. representation that such use or results of such use would not infringe privately owned rights; or

3. endorsement or recommendation of any specifically identified commercial product, process, or service.

Any views and opinions of authors expressed in this work do not necessarily state or reflect those of the United States Government, or its contractors, or subcontractors.

\section{Printed in the United States of America}

Prepared for

U.S. Department of Energy 
Keywords: MST, ISDP

Retention: Permanent

\section{Analysis of Harrell Monosodium Titanate Lot \#46000619120}

K. M. L. Taylor-Pashow

September 2012

Savannah River National Laboratory Savannah River Nuclear Solutions, LLC Aiken, SC 29808

Prepared for the U.S. Department of Energy under contract number DE-AC09-08SR22470. 


\section{REVIEWS AND APPROVALS}

AUTHORS:

K. M. L. Taylor-Pashow, Separations and Actinide Science Programs

Date

TECHNICAL REVIEW:

T. C. Shehee, Separations and Actinide Science Programs

Date

APPROVAL:

S. D. Fink, Manager

Date

Separations and Actinide Science Programs

S. L. Marra, Manager

Date

Environmental \& Chemical Process Technology Research Programs

D. J. Martin, Manager

Date

H Tank Farm Engineering 


\section{EXECUTIVE SUMMARY}

Monosodium titanate (MST) for use in the Actinide Removal Process (ARP) must be qualified and verified in advance. A single qualification sample for each batch of material is sent to SRNL for analysis, as well as a statistical sampling of verification samples. The Harrell Industries Lot \#46000619120 qualification and the 13 verification samples met each of the selected specification requirements that were tested and, consequently, the material is acceptable for use in the ARP process. 


\section{TABLE OF CONTENTS}

LIST OF TABLES vi

LIST OF ABBREVIATIONS vi

1.0 Introduction 1

2.0 Experimental Procedure. 1

3.0 Results and Discussion... 1

4.0 Conclusions 2

5.0 References 3

\section{LIST OF TABLES}

Table 3-1. Weight percent, pH, and Density Results for All Samples ........................................ 2

Table 3-2. Results of the Qualification Sample Analyses ............................................................. 2

\section{LIST OF ABBREVIATIONS}

$\begin{array}{ll}\text { ARP } & \text { Actinide Removal Process } \\ \text { CSSX } & \text { Caustic Side Solvent Extraction } \\ \text { DF } & \text { decontamination factor } \\ \text { IC } & \text { ion chromatography } \\ \text { ICP-ES } & \text { inductively coupled plasma - emission spectroscopy } \\ \text { MCU } & \text { Modular CSSX Unit } \\ \text { MST } & \text { monosodium titanate } \\ \text { SRNL } & \text { Savannah River National Laboratory } \\ \text { TIC-TOC } & \text { total inorganic carbon - total organic carbon } \\ \text { VOA } & \text { volatile organic analysis }\end{array}$




\subsection{Introduction}

Harrell Industries is under contract with Savannah River Remediation (SRR) to provide MST for use in the Actinide Removal Process (ARP). A 1-L qualification sample from Lot \#46000619120 was sent to the Savannah River National Laboratory (SRNL) to confirm the material meets certain requirements specified in the purchase specification. ${ }^{1}$

The vendor is also obligated to send verification samples from $~ 10 \%$ or more of the pails of MST product for each lot. The verification samples are selected from the entire inventory of pails so that the set of verification samples represents pails filled from the beginning to the end of the pail-filling operation for the entire lot of MST. For the verification of this lot, Harrell Industries sent 13 samples, one each from pails \#1,10, 20, 30, 40, 50, 60, 70, 80, 90, 100, 110, and 120 of 121 total pails.

SRR requested analysis of the qualification sample for weight percent MST, density, $\mathrm{pH}$, volatile organics, and particle size. They also requested analysis of the verification samples for weight percent solids, density, and $\mathrm{pH}^{2}{ }^{2}$ The work was controlled by a Task Technical and Quality Assurance Plan (TTQAP). ${ }^{3}$

\subsection{Experimental Procedure}

SRNL analyzed the qualification and verification samples for density, $\mathrm{pH}$, and weight percent solids. Density was measured using an electronic pipette in triplicate. The $\mathrm{pH}$ was measured by colorimetric $\mathrm{pH}$ strips, and the weight percent solids were measured in triplicate using a MettlerToledo Halogen Moisture Analyzer HG63 instrument.

Aliquots of the qualification sample were removed under well mixed conditions to provide subsamples for each of the analyses. SRNL performed the following analyses: volatile organic analysis (VOA) and particle size using a Microtrac ${ }^{\circledR}$ S3500 analyzer.

\subsection{Results and Discussion}

The results of the weight percent, $\mathrm{pH}$, and density measurements are reported in Table 3-1, while the results of the additional qualification sample analyses are reported in Table 3-2. 
Table 3-1. Weight percent, pH, and Density Results for All Samples

\begin{tabular}{|c|c|c|c||}
\hline Sample ID & $\begin{array}{c}\text { Weight \% Solids } \\
\text { (Standard Deviation) }\end{array}$ & $\mathbf{p H}^{\mathbf{a}}$ & $\begin{array}{c}\text { Density }^{\mathbf{b}}(\mathbf{g} / \mathbf{m L}) \\
(\% \mathbf{R S D})\end{array}$ \\
\hline Qualification & $15.59( \pm 0.096) \%$ & 12.0 & $1.127(0.01 \%)$ \\
\hline Pail \#1 & $15.73( \pm 0.205) \%$ & 12.0 & $1.127(0.07 \%)$ \\
\hline Pail \#10 & $15.78( \pm 0.155) \%$ & 12.0 & $1.128(0.03 \%)$ \\
\hline Pail \#20 & $15.64( \pm 0.046) \%$ & 12.0 & $1.118(0.30 \%)$ \\
\hline Pail \#30 & $15.65( \pm 0.121) \%$ & 12.0 & $1.128(0.03 \%)$ \\
\hline Pail \#40 & $15.77( \pm 0.098) \%$ & 12.0 & $1.127(0.12 \%)$ \\
\hline Pail \#50 & $15.82( \pm 0.032) \%$ & 12.0 & $1.124(0.38 \%)$ \\
\hline Pail \#60 & $15.75( \pm 0.078) \%$ & 12.0 & $1.125(0.05 \%)$ \\
\hline Pail \#70 & $15.62( \pm 0.066) \%$ & 12.0 & $1.125(0.12 \%)$ \\
\hline Pail \#80 & $15.65( \pm 0.030) \%$ & 12.0 & $1.127(0.11 \%)$ \\
\hline Pail \#90 & $15.64( \pm 0.116) \%$ & 12.0 & $1.122(0.15 \%)$ \\
\hline Pail \#100 & $15.49( \pm 0.040) \%$ & 12.0 & $1.127(0.05 \%)$ \\
\hline Pail \#110 & $15.51( \pm 0.076) \%$ & 12.0 & $1.123(0.10 \%)$ \\
\hline Pail \#120 & $15.66( \pm 0.169) \%$ & 12.0 & $1.123(0.05 \%)$ \\
\hline \multicolumn{3}{|l|}{} \\
\hline Average & $15.66( \pm 0.097) \%$ & 12.0 & $1.125(0.24 \%)$ \\
\hline Acceptable Range ${ }^{1} \%$ & $15-17 \%$ & $>10$ & no requirement \\
\hline
\end{tabular}

a) The uncertainty of the $\mathrm{pH}$ measurement is $0.5 \mathrm{pH}$ units.

b) Density measurements taken at $23^{\circ} \mathrm{C}$.

Table 3-2. Results of the Qualification Sample Analyses

\begin{tabular}{|c|c|c|c|c||}
\hline Property & Method & Result & Specification & Pass ? \\
\hline Volatile Organics & VOA & $33 \mathrm{ppm}^{\mathrm{i}}$ & $\mathrm{n}^{\mathrm{ii}}$ & $\mathrm{n} / \mathrm{a}$ \\
\hline Particle Size, $<0.8 \mu \mathrm{m}$ & Microtrac $^{\circledR}$ & $5.33 \mathrm{vol} \%$ & $<10 \mathrm{vol} \%$ & YES \\
\hline Particle Size, $>37 \mu \mathrm{m}$ & Microtrac $^{\circledR}$ & $0.15 \mathrm{vol} \%$ & $<1 \mathrm{vol} \%$ & YES \\
\hline $\begin{array}{c}\text { Particle Size, geometric standard } \\
\text { deviation (absorbance mode) }\end{array}$ & Microtrac $^{(}$ & 3.13 & $\leq 3.5$ & YES \\
\hline
\end{tabular}

The "Particle Size, geometric standard deviation" is defined as the 50th percentile result divided by the 16 th percentile result. Microtrac ${ }^{\circledR}$ results have a $10 \%$ analytical uncertainty. VOA results have a $20 \%$ analytical uncertainty.

\subsection{Conclusions}

Analyses of the Harrell Lot \#46000619120 MST material indicate the material falls within the specifications required for use at ARP.

\footnotetext{
${ }^{\mathrm{i}}$ Isopropanol $=33 \mathrm{ppm}$, all other analytes $=<0.25 \mathrm{ppm}$

${ }^{\text {ii }}$ Purchase specification does not include a specification for volatile organics, only total alcohol content of $<500 \mathrm{ppm}$.
} 


\subsection{References}

1. Specification for Purchase of 15 wt \% Monosodium Titanate (MST) for 96-H ARP, Specification No. X-SPP-H-00012, Rev. 6, November 2010.

2. C. Duffey, "MST Qualification and Verification”, X-TTR-H-00017, Rev. 0, February 2012.

3. K. M. L. Taylor-Pashow, "Task Technical and Quality Assurance Plan for Monosodium Titanate (MST) Qualification and Verification”, SRNL-RP-2012-00094, Rev. 0, March 2012. 


\section{Distribution:}

K. M. Fox, 999-W

S. D. Fink, 773-A

B. J. Giddings, 786-5A

C. C. Herman, 999-W

S. L. Marra, 773-A

F. M. Pennebaker, 773-42A

W. R. Wilmarth, 773-A

Records Administration (EDWS)

E. J. Freed, 704-56H

D. J. Martin, 241-152H

M. W. Geeting, 241-152H

T. A. Le, 766-H

A. R. Shafer, 704-27S

C. K. Chiu, 704-27S

S. E. Campbell, 241-152H

B. A. Gifford, 704-56H

R. M. Wolfenden, 704-56 H

K. L. Lang, 704-27S

P. R. Jackson, DOE-SR, 703-46A

K. H. Subramanian, 766-H

K. M. L. Taylor-Pashow, 773-A

T. C. Shehee, 773-A

T. B. Peters, 773-42A

M. R. Poirier, 773-42A

F. F. Fondeur, 773-A

D. T. Hobbs, 773-A 